\title{
Introduction: The Denk ich an Deutschland Television Film Series
}

\section{Margit Sinka}

Languages, Clemson University

Intended to provoke contemplation and discussion about collective identity in unified Germany, the Denk ich an Deutschland (When I think about Germany) television film series was commissioned by Bayerischer Rundfunk (Bavarian Broadcasting, BR) and Westdeutscher Rundfunk (West German Broadcasting, WDR) and was produced from 1997 to 2004 by megaherz gmbh. The complete series consists of twelve documentary films ranging from forty-five to sixty minutes ${ }^{1}$ with the first five (see Table 2) having been launched on BR and WDR as a set in October 1998.

Table 1: The Denk ich an Deutschland series

1. Augenblick (One Last Glimpse), Doris Dörrie and Werner Penzel

2. Das Wispern im Berg der Dinge (A Whispering in the Mountain of Things), Dominik Graf and Michael Althen

3. Kix?, Katja von Garnier and Uli Kerschbaumer

4. Niemandsland (No Man's Land), Andreas Kleinert

5. Angst spür ich wo kein Herz ist (I Notice Fear Where There Is No Heart), Sherry Hormann

6. Ein Fremder (A Stranger), Peter Lilienthal

7. Adeus und Goodbye (Farewell and Goodbye), Peter Patzak

8. Wir haben vergessen zurückzukehren (We Forgot to Return), Fatih Akin

9. Die Leopoldstrasse kills me, Klaus Lemke

10. Die Durchmacher, Leander Haußmann and Boris Naujoks

11. Herr Wichmann von der $C D U$ (Vote for Henryk!), Andreas Dresen

12. Familienreise (Family Trip), Michael Gutmann 
Three years later, approximately one week before four films from the second set of five were featured as a unit on the same two television stations (November 2001), the complete second set was highlighted under the Denk ich an Deutschland rubric as a focal point of the 2001 Hofer Filmtage, an annual international film festival. But, much as Fatih Akin's Wir haben vergessen zurückzukehren (We Forgot to Return, see Table 2) premiered on the ARD television network on 28 November 2001 separated from the others in its unit, the last two productionsAndreas Dresen's Herr Wichmann von der CDU (Vote for Henryk!, 2002) and Michael Gutmann's Familienreise (Family Trip, 2003)-also premiered independently. The Panorama division of the 2003 Berlin Film Festival aired Dresen's film, and the 2004 Munich International Documentary Film Festival showed Dresen's and Gutmann's contributions. ${ }^{2}$

\section{Table 2: The Denk ich an Deutschland series}

First Unit (October-November 1998)*

1. Andreas Kleinert, Niemandsland (2 and 3 October)

2. Dominik Graf, Das Wispern im Berg der Dinge (9 and 11 October)**

3. Doris Dörrie, Augenblick (15 and 18 October)

4. Katja von Garnier, Kix? (23 and 25 October)

5. Sherry Horman, Angst spür ich wo kein Herz ist (6 November)

Second Unit (October-November 2001)

1. Leander Haußmann, Die Durchmacher (27 October)

2. Klaus Lemke, Die Leopoldstraße kills me (3 and 5 November)

3. Peter Lilienthal, Ein Fremder (10 and 14 November)

4. Peter Patzak, Adeus und Goodbye (11 and 19 November)

5. Fatih Akin, Wir haben vergessen zurückzukehren (28 November), ARD

Separate Television Premieres

1. Michael Gutmann, Familienreise, (May 2004)***

2. Andreas Dresen, Herr Wichmann von $\operatorname{der} C D U($ Sept. 12, 2004)****

* All premieres on Bayerischer Rundfunk or Westdeutscher Rundfunk unless otherwise stated.

** $\quad$ Premiered at the Berlinale (Panorama division) in February 1997.

*** In connection with the Munich dok.fest

**** Premiered in February 2003 at the Berlinale (Panorama division), starting its long run in movie houses in April 2003. 
Thus, the twelve films of the series have never been shown together as a single unit. Indeed, several of the films have thrived on their own. Dresen's, for example, turned into an immense national success when it was shown in one movie theater after another, thereby retarding its appearance on television by more than a year (to the considerable chagrin of many bloggers from small towns across Germany who had to wait quite some time for the film to arrive in their areas). Dominik Graf's contribution, which won the prestigious Adolf-Grimme Award in 1999, has become a popular choice for introducing events thematizing the development of postwar German film or examining the effects of the World War II on later generations. Moreover, it is the only film of the series featured in Berlin's new Television Museum, where it can also be screened. Generally designated as an Einwanderungsfilm (immigration film), Akin's production-as well as Michael Gutmann's more recent contribution-has become a popular choice to deal with all kinds of emigration, immigration, and migration topics.

When particular films have been shown on their own, television commentators and those introducing the films at festivals and other events have stressed their connectedness to the entire series, yet they rarely elaborated on why this connectedness should interest average viewers. Indeed, what might German audiences expect from a production designated as a "Denk ich an Deutschland film?" What kind of representation of collective identity should Germans expect from this iconic yet ambiguous phrase penned by Heinrich Heine over 150 years ago?

Only the initial line of Heine's Loreley is as famous as the following two lines from his poem Nachtgedanken (Night Thoughts, 1843): "Denk ich an Deutschland in der Nacht,/ Dann bin ich um den Schlaf gebracht." 3 These lines-written in the midst of his twenty-five year sojourn in Paris (interrupted only once by a visit home in 1843) and steeped in critical longing and melancholic nostalgia-typically have been used to justify opening a floodgate of complaints about Germany, or at best, heartfelt, complex, and melancholic ruminations on the ever-problematic German national identity. That Heine's poem contains rather positive views of Germany-"a thoroughly healthy country" (ein kerngesundes Land)-or that the descriptions of restlessness and the subsequent flow of tears may not, 
after all, stem from Heine's attitude toward Germany, but rather from his sadness at not having been able to visit his mother in Germany for many years, ${ }^{4}$ have barely affected this traditional interpretation of the lines.

Nevertheless, recent years have revealed a new trend in usage: the line about losing sleep in the context of thinking about Germany is now rarely included with the overall quote. One of the many examples reflecting this trend is the Denk ich an Deutschland survey of prominent national and international personalities published by Die Welt on 9 June 2006, shortly before the 2006 World Cup of soccer hosted by Germany. Although the term "at night" does appear in Gordian Maugg's television documentary film on Heine's life, Denk ich an Deutschland in der Nacht (Norddeutscher Rundfunk, 2005), this phrase also is now frequently eliminated, leaving only the fragment "When I think of Germany."

Despite these attempts to make the shortened phrase more innocuous, thus encouraging the inclusion of positive comments about Germany, as a whole it still reverberates with contradictory associations and ambivalent musings about German national identity, prompted by knowledge of the conscious borrowing from Heine. Such tensions will continue to be associated with the phrase, because tensions of all sorts plagued Heine his entire life-tensions between rigorous philosophical thinking and sensuous worldly pleasures, between Christianity and Judaism, freedom and censorship, love of beautiful German landscapes and hatred of Prussian authority structures. Because ruptures characterize Heine's writings the most ${ }^{5}$ ruptures also typify the responses given to the Denk ich an Deutschland phrase, even though attempts to mediate and synthesize-concerns likewise associated with Heine particularly in regard to his writings on France and Germanysurface as well.

Exemplifying these ambivalences traditionally associated with Heine's sentence fragment were the audio recordings of Deutschlandradio's Denk ich an Deutschland series initiated five days before the 150th anniversary of Heine's death on 12 February 2006 and continued to the end of 2007. Prominent citizens chosen from various walks of life, such as architecture, business, literature, media, and politics, were asked to respond to the Denk ich an Deutschland phrase with comments on their "personal experiences with and relationship 
to" Germany. ${ }^{6}$ On the ten-minute segments, a new one appearing on the Deutschlandradio website each week, the contributors have combined emotional responses, rational commentaries, and often artistic elements, such as musical scores or poetry lyrics. The contributions have turned into a kaleidoscopic compendium of feelings and thoughts on contemporary German identity. Many speakers praise various facets of the German language, landscapes, authors, diverse kinds of music, and, not least, German bread. Most are pleased at the variety found in their country, yet dream of even more heterogeneity. While many note unsavory characteristics, including pessimism, absence of spontaneity, lack of risk taking, and excessive planning, they tend to connect these negative aspects with personal lives rather than with inherent national traits. If they do have restless nights, some say, it is not because of "Germany," but rather due to personal matters. Strikingly, only a small number of these audio compilations on German identity contain references to the problematic historical heritage or to remembrance of the past as a necessary component of a national identity. In their stress on the present and the future, they nonetheless tend to follow the Deutschlandradio's prodding to include both critical statements and positive visions, and thus often thematize the interplay of opposites.

Hence, by asking directors to expand filmically on Heine's famously elastic Denk ich an Deutschland phrase, rather than respond for example to the word Heimat (a more restrictive concept despite arguably successful recent attempts to reframe it into a more fluid construct), Bayerischer Rundfunk and Westdeutscher Rundfunk seemed to invite a wide range of pluralistic views comparable to the variety that accrued on the Deutschlandradio website. The fact that mainly feature film directors rather than documentary filmmakers were chosen for the sixty-minute documentaries appears less puzzling if one conjectures that filmmakers particularly well-known for exceptional creativity could enable thoughtful audiences-and the viewers of issue-oriented, late evening programming by the BR and WDR are expected to be thoughtful-to extend and enrich their views on German identity. Such a choice of directors also seems justified if one keeps in mind the trends occurring in current documentary filmmaking, reflected not only in the films themselves but also in the abundance of current scholarship on the nature of documentaries. 
While categories such as the six (e.g., expository, observational, or performative) elaborated by Bill Nichols in his seminal Representing Reality (1991) and Introduction to Documentary $(2001)^{7}$ may not suffice to classify all documentaries, they point strongly to the hybridity now dominating what was once considered a rather staid genre with strict parameters.

Yet, it is also possible that the feature film directors, asked to highlight aspects of reality only personally relevant to them ${ }^{8}$-a directive that observational documentarians especially would have been reluctant to follow-were meant to camouflage the political intent of the series. By launching the film series on the eve of the eighth Day of German Unity, 2 October 1998- BR and WDR clearly intended to offer a "contribution to unification" and to present "a political project for Germany after the elections." Indeed, not even a week had passed since the landmark 27 September 1998 Bundestag election had swept Chancellor Helmut Kohl and the CDU from political power after sixteen years, replacing them with the jubilant Gerhard Schröder and the first Red/Green coalition on the national level. With Germany having been granted yet another new beginning, especially politicians and media representatives attempted to steer a reluctant nation to refocus on an unsettled reunification matter: how to repair the fractured German identity.

Fear of accepting a collective identity and its attendant symbols, persistent ever since the demise of the Nazi dictatorship, still prevailed. While both postwar German states had been established "on the basis of explicit rejection of the national Socialist regime," each developed in accord with its victorious WWII occupying power different historical narratives that generated divergent shifts of values. ${ }^{10}$ As Gerd Gemünden puts it, "the fight for Germany's future" was "fought across its past." 11 With its focus on collective and personal memory, the Walser-Bubis controversy-initiated by the Friedenspreisrede that novelist Martin Walser held barely a week after the first Denk ich an Deutschland film was televised-also involved the role of the past in identity formation, and it too did not lead to the kind of broad consensus serviceable for forming a national identity.

Though not stated explicitly, the introduction to the Denk ich an Deutschland series on the website of megaherz, ${ }^{12}$ the firm entrusted by the broadcasters to produce the films, reveals that the films were 
meant to reframe the identity discourses prevalent nationwide. Instead of centering on problematic aspects of the past in order to form a collective identity with which most Germans could identifyfor example, regarding how to interpret a common past (the National Socialist era), how to integrate divergent pasts into a whole (those of the German Democratic Republic and the former Federal Republic), or how to reconcile contradictory perpetrator and victim discoursesthe films in the series were meant to broach national identity issues only with reference to the present and to the personal. It is doubtful, moreover, that this intent was problematized in any meaningful wayfor instance, by drawing on Maurice Halbwachs's topical idea that the past no longer exists and is always reconstructed within a social framework by needs of the present. ${ }^{13}$ In fact, it is difficult to shake off the nagging suspicion that despite its title, the series consciously was intended to minimize the tensions traditionally associated with Heine's fractured sentence, as well as to reduce the importance of the past in a national identity still open to reconfiguration.

In short, is a Schlussstrich (final line) mentality-that is, achieving closure or finality about the Nazi past and going on to other thingslurking behind the politically unassailable usage of Heine's line from Nachtgedanken? Or, stated differently, was the film series conceived as a promotion of German normality? If not, is it nonetheless a precursor to the "new patriotism" that has received so much attention since the 2006 soccer World Cup? In September and October 2006, even the liberal Die Zeit succumbed to the vestiges of the Sommermärchen euphoria ${ }^{14}$ by publishing the "new patriotism" essays that had been submitted to the Deutschlandradio's "SchwarzRot-Gold" (black-red-gold) series during the same time span. These essays had titles like "On the Way to a Good Mood" and "The End of Exalted Complaining."

Indeed, the text referring to the Denk ich an Deutschland series on the megaherz website fails to reassure in regard to these questions, for it sweeps aside all definitional difficulties pertaining to national identity. The site even proclaims that the mere focus on how Germans "live, think, act, and feel" results in films expressing the "difficult questions of German identity." 15 The BR representative announcing the second film in the series, Dominik Graf's Das Wispern im Berg der Dinge (A Whispering in the Mountain of Things), 
and referring to the following three as well, merely replaces terms. He informs viewers that the completed films on personal lives unequivocally express the directors' personal views on Heimat. Some critics are less convinced. Writing in the Frankfurter Allgemeine Zeitung of 30 October 2001 after having viewed the second set of five Denk ich an Deutschland films at the Hofer Filmtage, Michael Allmaier reveals that his initial enthusiasm for the concept of dispatching prominent filmmakers as reporters on their own private Germanys was considerably dampened by the films themselves (those of Leander Haußmann, Klaus Lemke, Peter Lilienthal, Peter Patzak, and Fatih Akin). Slyly, he concedes that the directors could certainly not have been expected to make a pilgrimage to the gigantic nationalist Hermann monument from 1875, but "since each of them emphasized the foreign/the strange or escaped into private matters, they made somewhat short shrift of thoughts about Germany." ${ }^{16}$ This criticism may be applicable to most of the films in the second set, but not to Lilienthal's.

Allmaier's reproach also does not and could not possibly pertain to either of the two films that I discuss later in this issue of German Politics and Society: Andreas Kleinert's Niemandsland (No Man's Land, 1998), the first film shown, and Andreas Dresen's Herr Wichmann von der $C D U$ (2003), the last film televised. Though both Kleinert and Dresen focus on the present, neither ignores the dichotomous tensions between the personal and the national expressed in Heine's Nachtgedanken. In Kleinert's case, I point to the strict boundaries set up on the narrative level between the national and the personal as Niemandsland depicts the 2005 Day of German Unity both in the life of Berlin and in the life of Charly, a marginalized individual. I then show how Kleinert deconstructs the dissonances and artificial syntheses he himself invents in order to reveal them as constructs that can and should be reconfigured by viewers in order to assimilate people at the margins. In Dresen's case, I first highlight the clashing relationship between a politician and the inhabitants of the marginalized Uckermark region of eastern Germany and then the means Dresen uses to erode the personal identity of the politician, an erosion largely responsibility for his inability to bridge the gap between national concerns and the personal concerns of the Uckermark's inhabitants. Though Dresen removes none 
of the tensions he establishes, he too-like Kleinert-appeals to viewers to initiate needed societal changes.

In the other article of this issue, Margaret McCarthy discusses five filmmakers in the series who generally make popular feature or television films, but uncharacteristically were obliged to meditate on a topic not always associated with mass appeal. The extent to which they agitate for national identity via idiosyncratic selfhood parallels their varying success in advancing their filmic practices and our notions of Germany beyond generic conventions. McCarthy emphasizes that the most interesting films among the five are ultimately those that play out new permutations between self and nation, modeling an existential Bildung (cultivation) that potentially alters the national imagery feeding a core German selfhood.

The remaining films of the Denk ich an Deutschland series will be discussed in upcoming issues of German Politics and Society. In my own article on Dominik Graf's documentary-situated in Munich's postwar theater and film world-I will examine the attempt to understand one's father on the basis of conflicting and insufficient information as a journey toward the formation of a personal identity that inevitably becomes in Graf's case also a journey toward the assumption of a serviceable national identity. I will show that Graf's journey into the past (including WWII) and back to the present is a prototypical West German journey, whereas Leander Haußmann's journey, as Lutz Kube will demonstrate in his analysis, is one conditioned at least in part by East German Ostalgie (nostalgia). In order to use the term Ostalgie-by now practically a household word-in fresh ways, Kube destabilizes it before applying it as a hybrid construct that includes playful elements, social criticism, and hypotheses on the insider culture (Nische) of the German Democratic Republic. In addition, he discusses the ways in which his understanding of Ostalgie in Haußmann's film complements other national identity issues raised in the process of thinking about Germany. Moreover, Kube's discussion of Haußmann's film and mine of Graf's intersect with contemporary discussions of memory formation, as well as personal and national uses of memory.

Uta Larkey's contribution on the filmmakers Peter Lilienthal, Peter Patzak, and Michael Gutmann highlights emigration, immigration, and migration and thus also the jarring demands on identity 
formation made by time (the past and the present), by space (various distinct environments in former and present countries of the filmic protagonists), and by mobility (the search for Heimat and/or the conscious decision to expand one's sense of home through migration). Strikingly, all three films stress intergenerational discourses on migration, Heimat, and identity, thus underlining the connectedness emphasized in current generation discourses prompted by contemporary Familienromane (family novels).

As a whole, the documentaries are too varied to be grouped together as private worlds illustrative of German national identity. The films themselves refute this assertion of the production company megaherz and the similar one of the BR commentator that emphasized the films as personal depictions of Heimat. Most are, however, firmly planted in the present, as the sponsors seem to have wished, and thus the filmmakers (with the exception of Graf, Lilienthal, and to a lesser extent Gutmann) barely touch upon Germany's WWII past, as the sponsors may also have wished. Yet, even the films anchored in the present do not end up being simple affirmations of German normality or of new patriotisms. Instead, the filmmakers emphasize changes: they justify the positive ones that have occurred in private lives, underline the need for others both on the personal and collective levels, and generally appeal to viewers to work for needed changes themselves-above all, by imagining identity as dynamic rather than static and reconfiguring identity constructs accordingly.

On a final note: those of us involved in investigating the Denk ich an Deutschland films hope that dynamic views of identity will impel the sponsors to expand the series with further productions. Although there are currently no concrete plans to extend the twelve-part series with additional films, it is quite possible, as Becky Seißler of megaherz noted in her correspondence with me (January 2007), that all of the films will be shown on television in the future as one entity. Given the widespread truism that it is in the nature of the television medium to repeat itself-if something appeared once, it is bound to reappear-the likelihood of being able to view all of the films again, especially under the ever-popular Denk ich an Deutschland rubric, remains strong indeed. 
MARgit Sinka (B.A. Baldwin-Wallace College; M.A. Middlebury College; Ph.D. University of North Carolina) is Professor of German and Head of Clemson University's German Section. She has published on medieval literature, genre studies (novella; post 1945 short stories), modernism, contemporary literature, and film. She contributed a chapter on Berlin symbolism and the "Generation Berlin" to Berlin: The Symphony Continues (Berlin, 2004) and one on Berlin's Holocaust memorials to Victims and Perpetrators: 1933-1945 and Beyond. (Re)Presenting the Past in Post-Unification Culture (Berlin, 2006). She co-authored Culture through Film (Newburyport, 2005) and is coauthoring Walking Berlin, scheduled for publication in 2007/08.

\section{Notes}

1. Only Andreas Dresen's Herr Wichmann von der $C D U$ has two differing lengths-a 60-minute version for television and an 80-minute one for movie theaters.

2. Gutmann's film also had its television premiere in conjunction with this festival, widely known as dok.fest.

3. The translation is; "When I think of Germany at night, I am robbed of all sleep." More elegantly, the second phrase can be translated as: "...all my sleep takes flight," as the British Film Institute renders the lines quoted also at the outset of Hans-Jürgen Syberberg's Hitler, Ein Film aus Deutschland.

4. This conviction recently has been propagated by many, such as Joseph A. Kruse, the current director of Düsseldorf's Heinrich Heine Institute, who called Nachtgedanken a mother's day poem rather than a poem about Germany.

5. Ruth Klüger, Rede zur Verleihung der Ehrengabe der Heinrich-Heine-Gesellschaft am 16. Februar 1997 im Düsseldorfer Schauspielhaus. Available at http://heinrichheine.com/welcomed.htm.

6. See www.dradio.de/dlf/sendungen/denkichandeutschland/500898/.

7. Bill Nichols, Representing Reality. Issues and Concepts in Documentary (Bloomington, 1991) and Introduction to Documentary (Bloomington, 2001).

8. The megaherz website is: http://www.megaherz.org/content/main_produktionen_ serien_denk_ich_start.asp.

9. Rüdiger Heimlich, "Im 'Land unter dem Nebel'. Reihe mit Deutschland-Porträts prominenter Filmemacher." Frankfurter Rundschau, 2 October 1998.

10. Aleida Assmann, "Limits of Understanding: Generational Identities in Recent German Memory Literature," in Victims and Perpetrators: 1933-1945. (Re)Presenting the Past in Post-Unification Culture, eds., Laurel Cohen-Pfister and Dagmar Wienroeder-Skinner (Berlin, 2006), 32. 
11. Gert Gemünden, "Nostalgia for the Nation: Intellectuals and National Identity in Unified Germany," in Acts of Memory: Cultural Recall in the Present, eds., Mieke Bal et al. (Hanover, 1999), 120.

12. See note 3 .

13. Maurice Halbwachs, On Collective Memory. ed., and trans., Lewis A. Coser (Chicago, 1992).

14. The title of Sönke Wortmann's documentary film on the German national team's 2006 World Cup journey-Deutschland-ein Sommermärchen (Germany-A Summer's Tale, 2006)-is a play on Heinrich Heine's Deutschland-ein Wintermärchen (Germany-A Winter's Tale, 1844). The second official film title is Germany: A Summer's Fairytale. The word Sommermärchen (summer fairy tale) has turned into an apt metaphor for the cheerful, spontaneous demonstrations of national pride evident throughout Germany during the World Cup games.

15. See note 3.

16. Michael Allmaier, "Ein Mosaik von Heimat: Novitäten bei den Hofer Filmtagen," Frankfurter Allgemeine Zeitung, 30 October 2001. 